論 文

\title{
金型摇動化圧下方式と潤滑による鍛造荷重低減特性
}

—— 鍛造型大圧下加工による微細粒鋼創製技術 II 三宅 勝* 矢崎 拓郎* 曾谷 保博*

\section{Development of Load Reduction Technology by Swing-Type Forging and Lubrication for Large-Deformation Forging by High-Speed Large-Reduction Forging}

\author{
— Production Technology for Fine Grained Steel by Large Deformation Forging I \\ Masaru MIYAKE*, Takuro YAZAKI * and Yasuhiro SODANI* \\ (Received on August 10, 2011)

\begin{abstract}
To reduce the forging load of the proposed large deformation forging technology, a new type of forging system is proposed. In this forging system, the contact length between forging dies and a work can be reduced by adjusting the swing motion of the dies during forging. This swing motion results in load reduction because contact length is a dominant factor of the load for this type of forging. Also, this forging technology is relatively stable when using lubrication because of its basic up-and-down motion. In this study, load reduction effect with the newly proposed forging system and lubrication are examined by laboratory-scale experiments and FE analysis. It appears that a nearly $30 \%$ load reduction can be achieved by the swing-type forging compared with the flying-type forging under the condition of a large thickness reduction. Width spread is also reduced by the swing type forging because contact length has a large influence on a material's lateral flow. Moreover, another $20 \%$ to $30 \%$ load reduction is confirmed and seizure on the forging dies was prevented by lubrication.
\end{abstract}

Key words: forging, large deformation, large reduction, fine grained steel, hot strip, lubrication.

\section{1. 緒 言}

著者らは，鋼板の熱間圧延ラインでの結晶粒微細化や粗 加工工程のコンパクト化を目的として, 熱間圧延工程の粗 加工に圧下量制約のない 1 パス大圧下を可能とする鍛造型 板厚圧下加工技術の導入を提案し, 前報 ${ }^{1)}$ にてその負荷特 性と変形特性について報告した。本加工技術では，材料と 金型間の摩擦による圧力上昇，いわゆるフリクションヒル が大きく成長するため，熱間スラブの 1 パス大圧下では非 常に高い加工力が必要である. このため, 本加工技術の実 用化のためには鍛造荷重の大幅な低減が必要と考えられる.

鍛造方式は金型形状や圧下条件の自由度が高く，圧下パ ス間の材料送り量を低減することにより鍛造荷重を低減す ることができる．しかしながら，大量生産ラインである熱 間圧延ラインへの導入を前提とすると, 生産性を落とさず に鍛造荷重を低減することが重要となる．熱間圧延での荷 重低減のため各種潤滑剂が使用されているが ${ }^{2)}$, 圧延では 圧延材とロール間に作用する摩擦力によって加工が成り立 っており，過度の潤滑性はスリップを発生させ，特に先端

\footnotetext{
*JFE スチール(株), スチール研究所 テ260-0835 千葉市中央区川崎町1番地 Steel Research Laboratory, JFE Steel Corporation, 1-Kawasaki-cho, Chuo-ku, Chiba 260-0835, Japan.
}

部では噛み込み不良が発生しやすくなる ${ }^{3)}$ 。これに対し， 本加工法では，基本動作として材料を上下方向に圧下する 方式であることから，潤滑を導入しても安定した大圧下加 工が可能である，また，鍛造荷重を低減するとともに金型 摩耗抑制や焼付防止等，金型材の耐用度の観点からも潤滑 が重要な役割を果たすと思われる ${ }^{4)}$.

本報では，鍛造型板厚大圧下による大ひずみ加工の実用 化技術として，鍛造荷重低減のための金型摇動化機構を提 案し，実験と数值解析によりその負荷特性と幅広がり特性 を明らかとする。また，潤滑剤適用による鍛造荷重低減効 果と金型焼付き防止効果について検討する.

\section{2. 鍛造型板厚大圧下における荷重低減技術}

\section{1 圧下方式による荷重低減技術}

本板厚大圧下加工法では，基本的に材料を上下方向に圧 下寸ることから，圧下下死点にて最大荷重が発生する。こ の際の鍛造荷重 $P$ は，簡易的に式(1)で表わされる.

$$
P=Q p \cdot k m \cdot l_{d} \cdot W
$$

$Q p$ は摩擦による圧力上昇の影響を表す圧下力関数, $\mathrm{km}$ は 材料の平均変形抵抗， $l_{d}$ は金型と材料との接触長，そして $W$ は材料の板幅である. 式(1)より，鍛造荷重は金型と材料 の接触長 $l_{d}$ に比例するため， $l_{d}$ を短縮することにより鍛造 
荷重の低減が可能である，そこで，材料の送りピッチ $f$ を 変更せずに $l_{d}$ を短縮する技術として，金型を回転させなが ら圧下寸る方式を考案した. Fig.1 に, 前報で検討した上下 方向の圧下方式（平行圧下方式あるいは Flying type）と， 新たに考案した圧下方式（金型摇動化圧下方式あるいは Swing type）の基本動作を示す。平行圧下方式では，圧下 下死点での接触領域長 $l_{d}$ は $L_{f}+L_{s}$ であるのに対し, 金型摇 動化圧下方式では圧下中に金型の自転運動(回転角度 $\varphi$ )に より金型傾斜部を材料から離すことにより，圧下下死点で の接触領域長は $L_{f}$ のみなる。 このように, 本技術では圧 下下死点での接触長 $l_{d}$ が縮小寸ることから, 鍛造荷重 $P$ を 低減することが可能である.
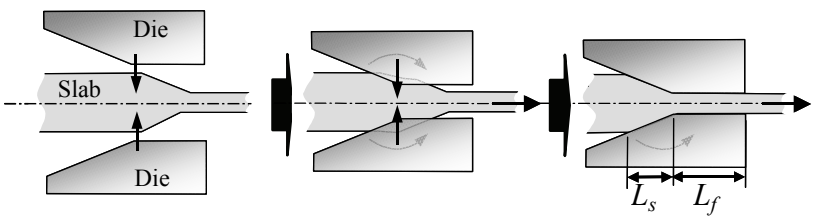

(a) Flying type motion
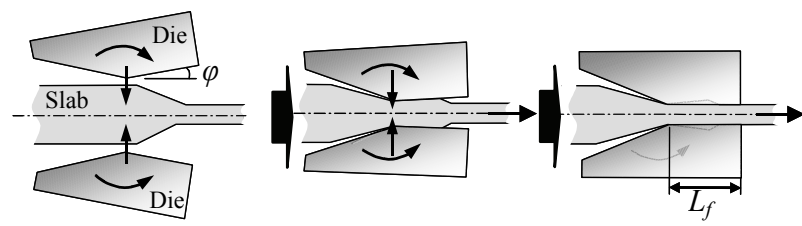

(b)Swing type motion

Fig.1 Basic concept of swing type forging

Fig.2 は, 板厚大圧下加工にて生じる板幅変形の模式図で ある。前報 ${ }^{1)}$ にて，平行圧下方式における材料の最小幅広 がり量 $\Delta W\left(=W_{1}-W_{0}\right)$ は圧下下死点における幾何学的傾斜 部接触長さ $L_{s}$ にて整理できることを示した. 金型摇動化圧 下方式では，圧下初期に金型傾斜部が材料と離れて接触長 が低減することから, 幅広がり量が低減することが期待で きる。
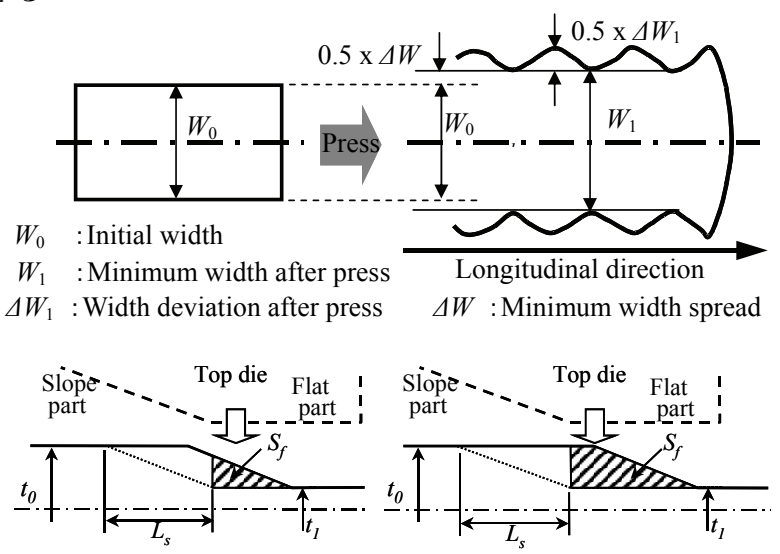

$L_{s}$ : Geometrical contact length with slope part of the die

$S_{f}$ : Geometrical pressed area by flat part of the die
(a) Case of $f \leq L_{s}$
(b) Case of $f>L_{s}$

Fig.2 Parameters to explain width spread behavior

以上，金型摇動化圧下方式では金型と材料の接触長が短 くなることにより，鍛造荷重と幅広がりの低減効果が期待 できる. そこで, 試験片全長の断続加工が可能な鍛造試験 装置を製作し，検証実験を行った。

\section{2 試験装置の概要}

Fig.3 に, 製作した試験装置の圧下機構の原理と金型軌跡, そして金型形状を示す. (a)の平行圧下方式は，上下各々の スライダーに取り付けた各 2 本のクランク軸を同位相にて 回転させることにより，上下の金型圧下面の平行部が水平 方向を保ったまま円軌道を描いて圧下を行う。本装置のク ランク半径 $R$ は $13.5 \mathrm{~mm}$ である。また，(b)の金型摇動化圧

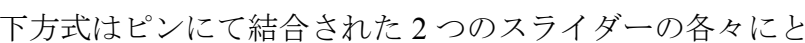
りつけたクランク軸の位相をずらして回転させることによ り，大きな楕円公転軌道を描きながら金型が所定の角度だ け自転する機構とした，本装置の金型自転の回転角度 $\varphi$ は $9.2^{\circ}$ である. 金型摇動化圧下方式では，圧下後の材料の板 厚凹凸が最小となるように，金型の回転挙動を考慮して圧 下面平行部に 4 段階の傾斜を付与した。圧下パス間の材料 の送りは，金型前後に設置したピンチロール制御にて実施 する. 平行圧下方式と金型摇動化圧下方式は圧下機構以外 の部分は共通であり, 最大荷重 $1.5 \mathrm{MN}$ ，モー夕動力 $75 \mathrm{~kW}$ そして毎分 100 サイクルの高速鍛造加工を行う.

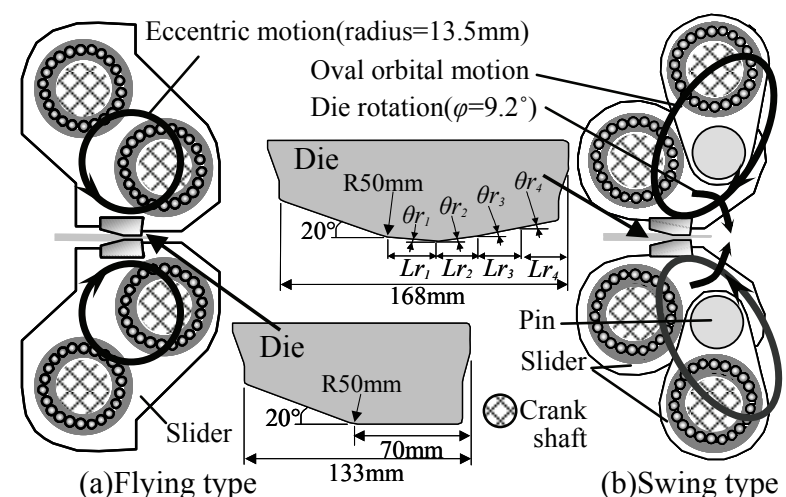

Fig.3 Schematics of employed forging equipment

\section{3 実験条件}

金型摇動化圧下方式による荷重低減挙動を検証するため, 供試材として硬質鉛 $(0.9 \mathrm{at} \%$ アンチモン含有)を使用した鍛 造実験を行った. 金型材質はSKD61 で圧下面はフライス加 工のままである。供試材寸法は厚み $25.4 \mathrm{~mm} \times$ 板幅 $100 \mathrm{~mm}$ ×長さ $1000 \mathrm{~mm}$ (実機想定に対するモデル比 $1 / 10$ 相当)であ る. 設定圧下率 $r_{s}$ を $50 \%, 70 \%$ の条件としたが，鍛造装置と 金型の弾性変形により実績圧下率 $r_{a}$ は各々 $43 \%, 65 \%$ となっ た.パス間送り $f$ は2 25 50mm の範囲で無潤滑条件である.

\section{4 実験結果と考察}

（1）鍛造荷重低減効果 Fig.4 に各々の圧下方式における送 りピッチ $40 \mathrm{~mm}$ の条件での鍛造荷重の推移を示す．各圧下 パスでの最大荷重に若干のばらつきが見られるものの，供 試材として硬質鉛を使用していることから先端から尾端に かけての鍛造荷重の変動は少なく, 各圧下パスでの最大荷

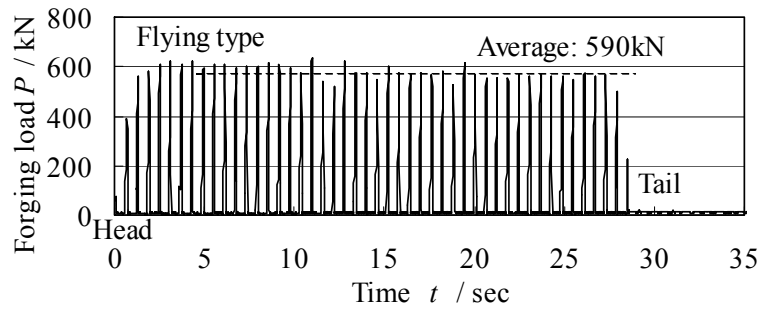

(a) Flying type experiment 


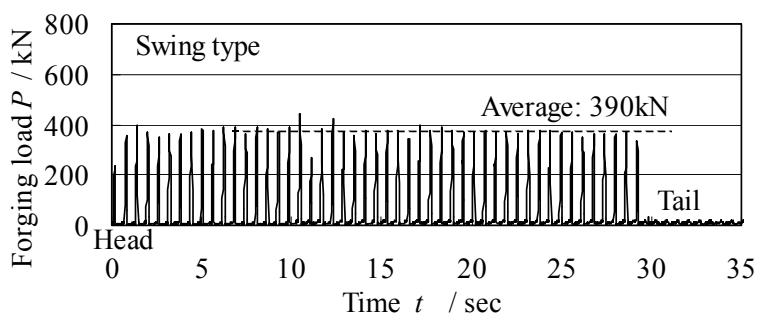

(b) Swing type experiment

Fig.4 Example of forging load behavior $\left(r_{a}=65 \%, f=40 \mathrm{~mm}\right)$

重の平均值を評価值とした。金型摇動化圧下方式は平行圧 下方式に対し鍛造荷重が約 $30 \%$ 低減 $(590 \mathrm{kN} \rightarrow 390 \mathrm{kN})$ して おり, 大きな荷重低減効果が得られている.

Fig.5 は 1 回の圧下動作中の代表的な荷重推移であるが, 平行圧下方式では金型と材料が接触した後はほぼ時間に比 例して接触長が増加することから, 圧下下死点に至るまで 鍛造荷重もほぼ線形に増加し, その後, 金型の上昇ととも に急速に荷重が低減する。これに対し, 金型摇動化圧下方 式では荷重の立ち上がりは緩く, かつ最大荷重点を過ぎた 後も金型の自転により緩やかに荷重が減少している.

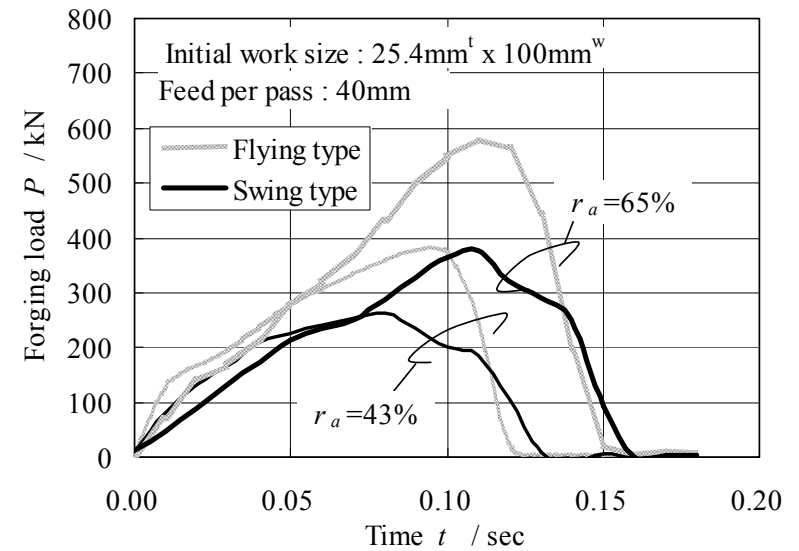

Fig.5 Behavior of forging load history of flying type forging and swing type forging $\left(r_{a}=43 \%, 65 \%, f=40 \mathrm{~mm}\right)$

Fig.6 は，鍛造荷重に及ぼす送りピッチの影響である(実 績圧下率 $\left.r_{a}=65 \%\right) . \triangle$ 及びム印が実験結果であり，実線は 数值解析による計算結果である. 数值解析には有限要素解 析ソフトAbaqus-explicit を用いた. Table1 に示す物性值を 用い，試験機の金型運動軌跡を忠実に再現した。理論計算 で設定する金型-材料間の摩擦係数を 0.22 とすると, 実測 荷重と計算荷重は Fig.6 に見られるように良好な一致を示 し, 平行圧下方式と比較して金型摇動化圧下方式にて大き な荷重低減効果が得られている. 数值解析結果では, 送り ピッチが大きい領域で荷重低減効果が若干縮小しているが,

Table1 Analytical conditions

\begin{tabular}{c|l|l}
\hline \multirow{2}{*}{ Die } & Young's modulus/ GPa & 206 \\
\cline { 2 - 3 } & Poisson's ratio & 0.3 \\
\hline \multirow{3}{*}{ Work } & Young's modulus/ GPa & 25 \\
\cline { 2 - 3 } & Poisson's ratio & 0.44 \\
\cline { 2 - 3 } & Flow stress / MPa & $37 \varepsilon^{0.15} \dot{\varepsilon}^{0.042}$ \\
\hline
\end{tabular}

この傾向は Fig.1 で示した接触領域の大小関係で説明でき る. すなわち, 送りピッチ $f\left(=L_{f}\right)$ が大きくなるほど全体接触 領域 $L_{f}+L_{s}$ に対寸る金型傾斜部の接触領域 $L_{s}$ の割合が低下 するため，荷重低減の割合も低下寸るものと考えられる.

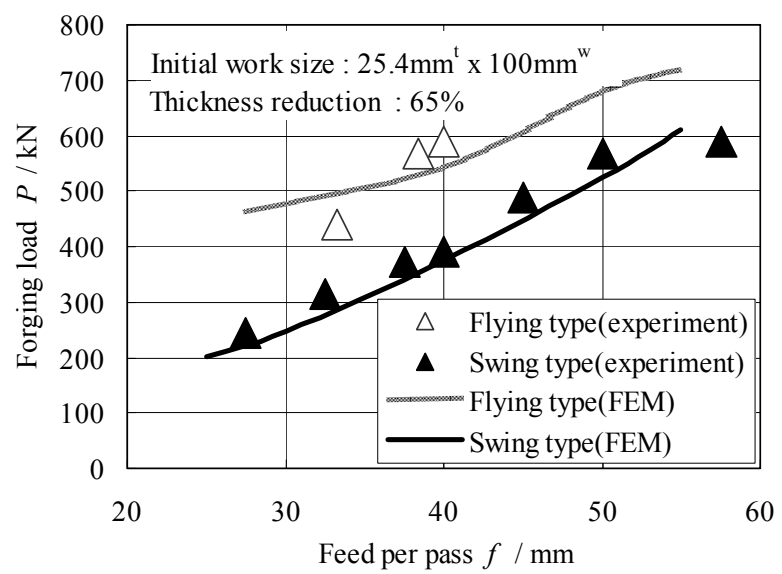

Fig.6 Comparison of forging load between flying type forging and swing type forging versus feed per pass

(2) 幅広がり挙動 Fig.7 は，最小幅広がり量 $\Delta W$ に対する 送りピッチの影響である。金型摇動化圧下方式では平行圧 下方式に比較して幅広がり量が低減しており，送りピッチ が大きくなるほどその効果が大きくなっている。これは， 圧下中の幅広がり変形量は変形域前後の非変形領域から受 ける拘束にて抑制されることから，材料と金型の接触長 $l_{d}$ が短いほど幅方向変形が小さくなるためである．平行圧下 方式では送りピッチ $f$ に比例して接触長 $l_{d}$ が増大するのに 対し，金型摇動化圧下方式では金型の自転運動により接触 領域が短い状態を保ちながら緩やかに下流側に移動するた め, 接触長 $l_{d}$ に対する送りピッチ $f$ の影響が小さいものと 考えられる.

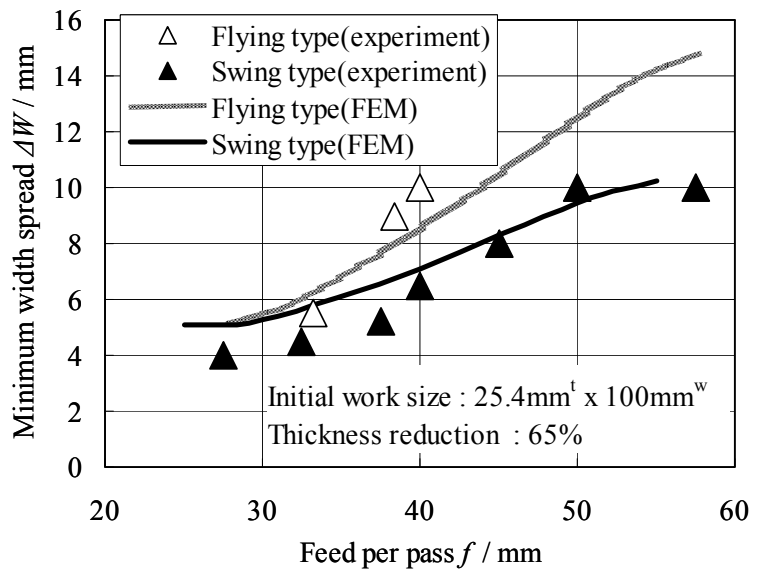

Fig.7 Comparison of width spread between flying type forging and swing type forging versus feed per pass

\section{3. 熱間潤滑適用による荷重低減特性}

\section{1 実験方法}

金型摇動化圧下方式での更なる荷重低減を図るため，熱 間鋼を用いた潤滑実験を行った. Fig.8 に実験手順の概略を 示す，供試材の温度は，長手方向中央位置にて熱電対を側 
面板厚中心部から板幅中央付近まで挿入して測定した．供 試材を電気式加熱炉で $1473 \mathrm{~K}$ まで加熱後に抽出し, 約 1 分 の放冷の後, 熱電対指示值が $1323 \mathrm{~K}$ となった時点より鍛造 を開始して全長にわたり板厚圧下を行った.この条件では, 供試材の長手方向中央位置での圧下時温度が約 $1273 \mathrm{~K}$ とな る。潤滑剤の塗布は，上下各々の金型圧下面に対し，金型 下流側直近より供試材の幅より広い領域に向けてエアーア トマイズ方式(圧力 $0.4 \mathrm{MPa}$ )にて常時吹き付けた.

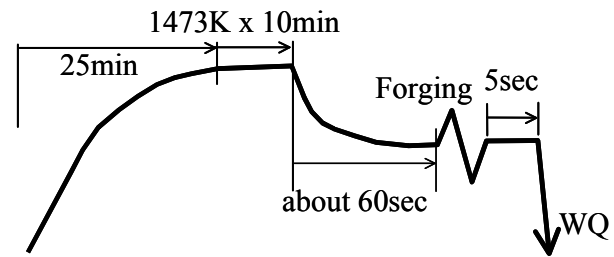

Fig.8 Schematics of experimental flow

而焼付性や耐摩耗性等の金型耐用度の観点から，金型温 度上昇に対する潤滑剤の影響も調査した。圧下中の金型温 度を測定するため, Fig.9 に示すように上金型の金型傾斜部 と平行部の交点より下流側 $20 \mathrm{~mm}$ の位置にて, 金型裏面よ り幅方向 $5 \mathrm{~mm}$ ピッチで圧下面からの深さが 2,6,11mm とな る位置まで $\Phi 1.2 \mathrm{~mm}$ の穴をあけ， $\Phi 1 \mathrm{~mm}$ の熱電対を挿入し てセラミクス系ボンドにて固定した。
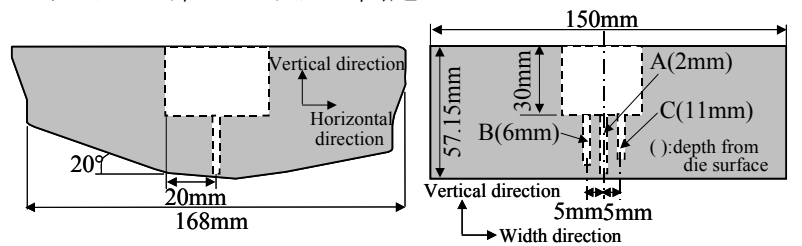

Fig.9 Schematics of the die with thermo-couple to measure die internal temperature

\section{2 実験条件}

本研究では, 単純組成鋼の組織微細化による高強度化を 目的としていることから，供試材として合金成分を含まな い Si-Mn 鋼( $0.14 \% \mathrm{C}-0.64 \% \mathrm{Mn})$ を使用した. 供試材の寸法は, 厚み $25.4 \mathrm{~mm} \times$ 板幅 $60 \mathrm{~mm} \times$ 長さ $1000 \mathrm{~mm}$, 実績圧下率 $r_{a}=$ 43〜 82\%, そして送りピッチ $f=35 \mathrm{~mm}$ の条件である.なお, 潤滑剤による荷重低減効果を摩擦係数の変化として定量表 現するため，前章と同様に有限要素法による数值解析を行 った。変形抵抗式には美坂・吉本の式 ${ }^{5)}$ を使用した。

使用した潤滑剂は非黒鉛系であり,グリース系(市販熱間 圧延油，基油 $85 \%$ +添加剤)と水溶性(市販熱間鍛造油, 水 $50 \%+$ 添加剂)の 2 系統を選択した. グリース系潤滑剤は吐 出量 $100 \mathrm{cc} / \mathrm{min}$, 水溶性潤滑剤は濃度 $10 \%$ と $50 \%$ の 2 水準 で吐出量 $160 \mathrm{cc} / \mathrm{min}$ の条件にて評価した.

\section{3 実験結果と考察}

（1）鍛造荷重低減効果 Fig.10 に，実績圧下率 $r_{a}=72 \%$ での 鍛造荷重推移例（潤滑剂不使用）を示す。熱間鋼を使用し た鍛造実験では，試験片先端の圧下開始後，尾端にいくほ ど圧下前の待機時間が長いことから温度低下量が大きく, 鍛造荷重が徐々に増加している。このため, 鍛造荷重の評 価は，熱電対による温度モニ夕位置である長手中央位置で の值にて行った（圧下時材料温度は約 1273K）。 Fig.11 は, 摩擦係数をパラメータとした数值解析結果と実測鍛造荷重
との比較であり, 無潤滑鍛造実験での荷重 $(1060 \mathrm{kN})$ は摩擦 係数 0.24 程度に相当している. 以後, 潤滑剂使用時の摩擦 低減作用による荷重低減挙動について, 摩擦係数 0.24 での 計算荷重 $P_{0}$ からの荷重低減率 $R_{P}\left(=\left(P_{0}-P\right) / P_{0} \times 100 \%\right)$ を定 義して評価する.

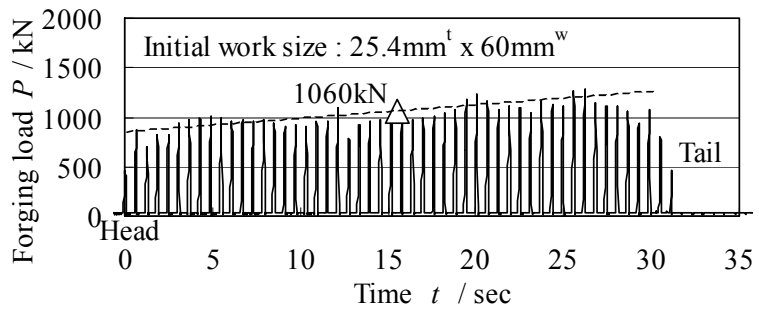

Fig.10 Example of forging load behavior in hot forging experiment $\left(r_{a}=72 \%, f=35 \mathrm{~mm}\right)$

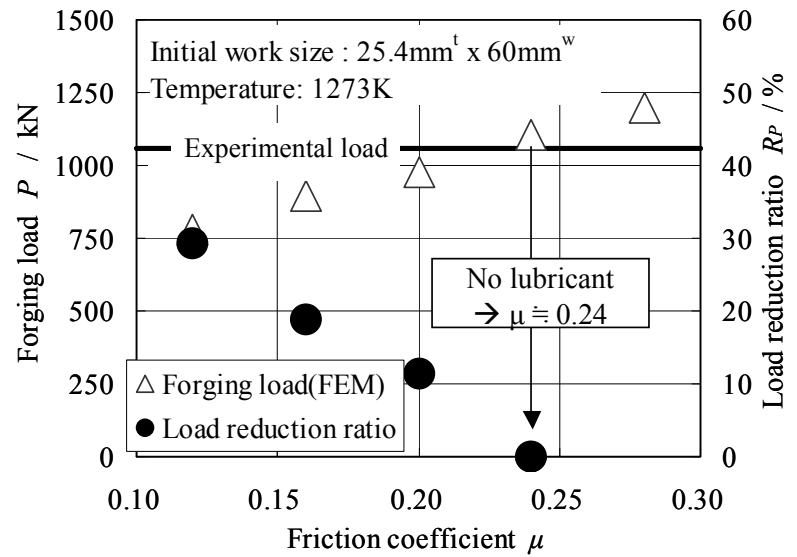

Fig.11 Comparison between experimental forging load and calculated results $\left(r_{a}=72 \%, f=35 \mathrm{~mm}\right)$

Fig.12 は，各潤滑剂使用時の鍛造荷重 $P$ と潤滑剂不使用 時の鍛造荷重 $P$ から算出した荷重低減割合である。実験結 果, 数值解析結果とも, 圧下率が大きいほど荷重低減率が 大きくなっている。これは，圧下率が大きいほど摩擦によ る圧力上昇が大きくなるため，潤滑による摩擦力の低減効 果が鍛造荷重の低減に大きく作用するためと考えられる. 荷重低減効果はグリース系の方が優れ，高圧下率領域にて 約 30\% と大きな荷重低減率が得られており，摩擦係数にし て 0.12 程度と大きく低減している. 水溶性潤滑剤では濃度 の影響はそれほど認められず，濃度 10\%でも高圧下率領域

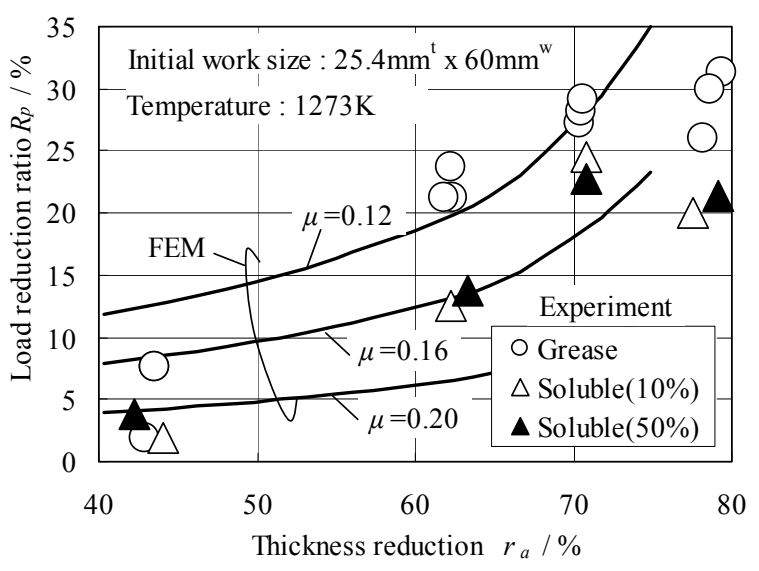

Fig.12 Behavior of load reduction ratio with lubrication 
にて $20 \%$ 程度の荷重低減効果を発揮している. グリース系 潤滑剤が圧下中も接触界面に薄膜として存在するのに対し， 水溶性潤滑剂は高温の金型表面に付着した直後に水分が蒸 発した後, 乾燥した添加剤成分が皮膜を形成しており，こ の皮膜が固体潤滑剤として作用しているものと考えられる. (2) 金型温度上昇抑制効果 Fig.13 は，グリース系潤滑剂 と水溶性潤滑剂濃度 $10 \%$ での金型温度測定結果例である $\left(r_{a}=72 \%\right)$. グリース系潤滑剤使用時の金型内部温度は無潤 滑条件とほぼ一致しているのに対し，水溶性潤滑剤使用時 は深さ $2 \mathrm{~mm}$ 位置にて最高到達温度が $70 \mathrm{~K}$ 程度低減してい る. 両者の対比から, いずれの潤滑剤でも潤滑作用による 摩擦発熱の軽減効果は非常に小さく, 水溶性潤滑剤では含 有水分の冷却作用により金型温度上昇が大きく抑制されて いるものと考えられる.

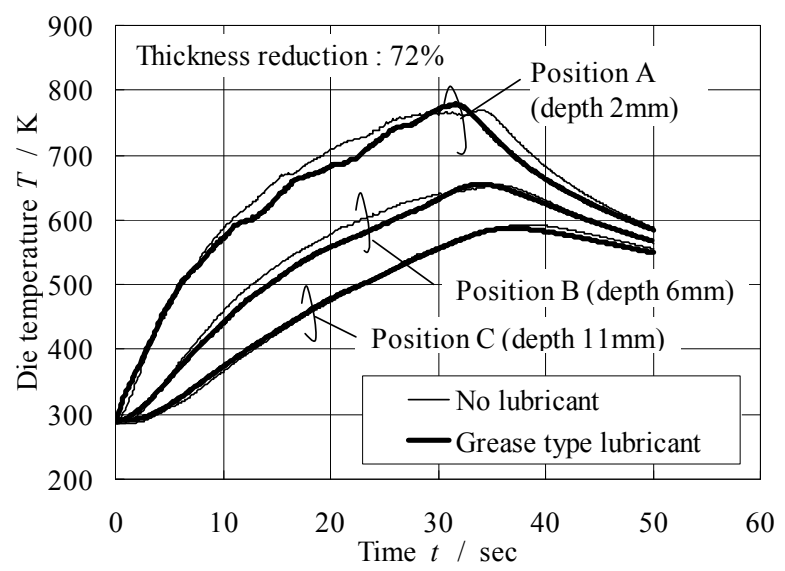

(a)With grease type lubrication

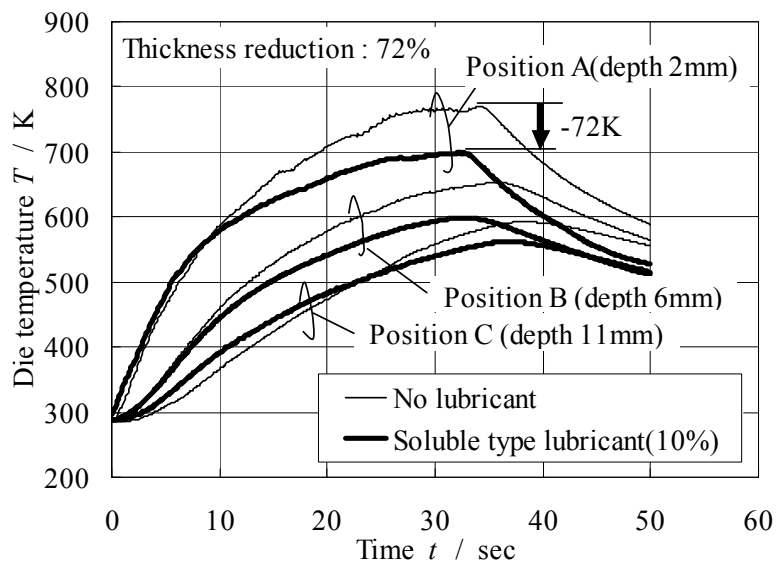

(b)With soluble type lubrication ( $10 \%$ concentration)

Fig.13 Die temperature history with- and without- lubrication

(3) 焼付防止効果 Fig.14 は, 無潤滑, グリース系潤滑剂, そして水溶性潤滑剂濃度 $10 \%$ での金型圧下面の状況と接触 式表面粗さ計にて測定した表面プロフィルであり，試験前 の機械加工のままと供試材 1 本を全長圧下した後の測定結 果である，熱間鋼の無潤滑実験では，高圧下率条件では直 ちに金型平行部に酷い焼付が発生するのに対し，潤滑剂使 用時はほとんど焼付が発生しなかった。潤滑剤適用により 接触圧力が低減するとともに，グリース系潤滑剤では強固 な薄膜が焼付を防止しているものと考えられる．また，比 較として圧下面に水のみを噴霧した実験でも焼付が若干軽
減したことから，水溶性潤滑剂では添加剤成分が形成した 固体潤滑膜による効果と，冷却による金型温度上昇抑制効 果が焼付防止に作用しているものと考えられる.

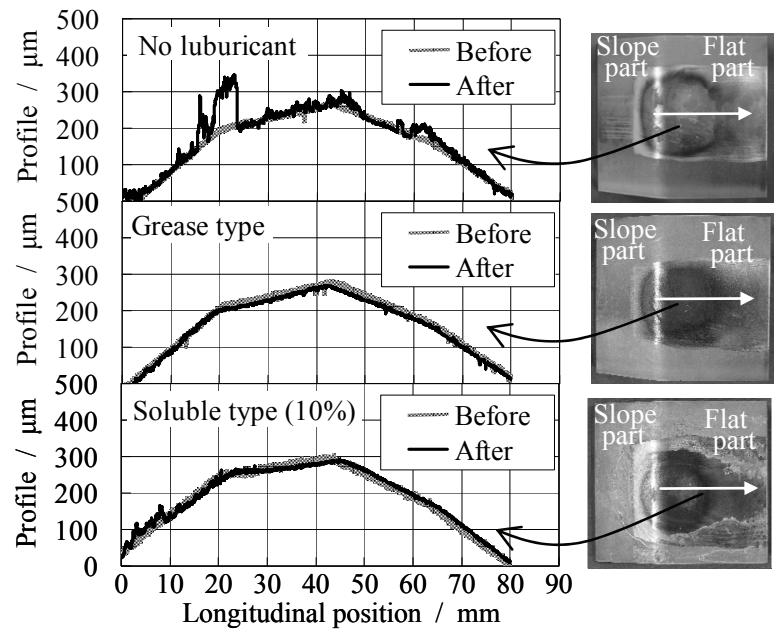

Fig.14 Comparison of seizure on die $\operatorname{surface}\left(r_{a}=72 \%\right)$

\section{4. 結 言}

鍛造型板厚大圧下加工での鍛造荷重低減技術として，新 たに考案した金型摇動化圧下方式の効果と熱間潤滑適用効 果について検討した．得られた結果を以下に示す。

1)金型摇動化圧下方式では，平行圧下方式に比べ高圧下率 領域にて 20〜30\%の荷重低減効果が得られた。 また，板厚 圧下によって生じる幅広がり量も低減する。

2)グリース系潤滑剤の適用により高圧下率領域にて 25\%以 上の鍛造荷重低減効果が得られ，金型摇動化効果 $30 \%$ と組 み合わせると $45 \%$ 以上の荷重低減効果となる.

3)水溶性潤滑剂は $10 \%$ の低濃度でも高圧下率領域にて $20 \%$ 程度の荷重低減効果が得られ，金型摇動化効果 $30 \%$ と組み 合わせると $40 \%$ 以上の荷重低減効果となる.

4)金型潤滑剂の適用により焼付きが大幅に低減する.また, 水溶性潤滑剂適用により金型温度上昇を大きく抑制できる.

今後，鍛造型板厚大圧下加工でのオーステナイト組織の 微細化挙動について報告を行う予定である.

\section{謝 辞}

鍛造試験装置の設計にあたり，株式会社 IHI の西井崇・ 百々泰 両氏より多大な協力を得た。ここに謝意を表する。

\section{参 考 文 献}

1) 三宅勝・矢崎拓郎・曾谷保博 : 塑性と加工, 52-610 (2011), 1208-1212.

2) 小豆島明・薛衛東・吉田良明 : 鉄と鋼, 93-11(2007), 681686.

3) 小豆島明・薛衛東・吉田良明 : 鉄と鋼, 93-5(2007), 367372.

4) 鳥海貴大 - 小豆島明 : 鉄と鋼, 97-7 (2011), 388-392.

5) 美坂佳助・吉本友吉 : 塑性と加工, 8-79(1967), 414-422. 